\title{
EFFECTS OF COMPOST MEDIA ON GROWTH AND FLOWERING OF PARVIFLOROUS GARDEN PANSY (VIOLA $\times$ WITTROCKIANA GAMS.)* PART II. PLANT FLOWERING AND DECORATIVE VALUE
}

\author{
Agnieszka Zawadzińska, Dorota Janicka \\ University of Agriculture, Department of Ornamental Plants, Janosika 8, 71-424 Szczecin, Poland \\ e-mail: agaz@agro.ar.szczecin.pl
}

Received: 19.09.2007

\begin{abstract}
Su m m a r y
The purpose of the studies was to determine the effects of media containing composts from sewage sludge and potato pulp on the flowering and decorative value of 'Butterfly Yellow with Blotch' parviflorous pansy. In the experiment 14 potting media, including 12 media made of 4 composts, were tested. The percentage of compost mixed with sphagnum peat was $25 \%, 50 \%$ and $75 \%$. The components of particular composts were as follows: I - municipal sewage sludge $70 \%$ and straw $30 \%$; II - municipal sewage sludge $70 \%$ and sawdust $30 \%$; III - municipal sewage sludge $35 \%$, potato pulp $35 \%$ and straw $30 \%$; IV - municipal sewage sludge $35 \%$, potato pulp $35 \%$ and sawdust $30 \%$. Two control potting media were used: 1 - sphagnum peat with Osmo-

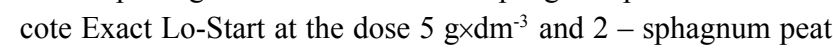

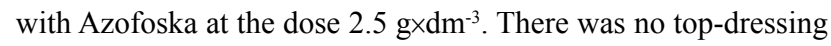
during cultivation. The pansies for whose cultivation a slow-release fertiliser was used turned out to have most flowers, but the plants cultivated in compost with peat at the ratio 1:1 had equally abundant flowering. At the generative stage, the pansies in control media were the most decorative and those growing in $25 \%$ of compost I, $75 \%$ of compost II and $50 \%$ of compost III and IV. On the basis of plant valuation scale, quality assessment and the abundance of flowering it was found that the media containing $50 \%$ of composts were optimal for pansy cultivation.
\end{abstract}

Key words: Viola $\times$ wittrockiana, compost, municipal sewage sludge, potato pulp, flowering

\section{INTRODUCTION}

The garden pansy (Viola $\times$ wittrockiana Gams.) called 'the flower of all seasons' is cultivated on the largest scale in USA, as a bedded and pot plant ( $\mathrm{S} \mathrm{t}$ a r t e k,
2003). According to flower size, pansies are divided into large-flowered -9-11.5 cm in diameter, medium-flowered $-6-9 \mathrm{~cm}$ in diameter; parviflorous $-4-6 \mathrm{~cm}$ in diameter and miniature of $2-3 \mathrm{~cm}$ in diameter, developed from Viola cornuta (K r a u s e et al. 2004).

The plants available on the market are multiple hybrids of Viola $\times$ wittrockiana which have been bred for over 150 years. At present, many cultivar groups may be cultivated in a year cycle - sown either in winter or spring, since they do not need low temperature at the seedling stage for the transition into the generative stage. They are heterositic cultivars $\mathrm{F}_{1}$ and $\mathrm{F}_{2}$, tolerant to light and stand, of a shorter production cycle than the cultivars with permanent traits. Apart from the appropriate choice of cultivar for the planned flowering time, the choice of media is an important factor of success in pansy cultivation ( $\mathrm{S} \mathrm{t}$ a r t e k, 2003). For many years pansies have been cultivated in peat substrate supplemented with traditional and slow-release fertilisers. The studies showed that the latter ones give better results, since they ensure an even supply of nutrients and continuous flowering. S t a r tek et al. (2006a) found that coconut media have a favourable effect on both the pansy emergence and further growth.

Due to limited peat resources and great costs of media import, it is advisable to search for alternate media, rich in nutrients with good physical properties. The mixtures of peat and composts made from municipal sewage sludge with different structure-forming materials may be such media (Ga r c i a-G o mez et al. 2002; Krzywy et al. 2007).

In the first part of the study, the effects of compost media on the pansy growth and conformation were

* Badania finansowane ze środków na naukę w latach 2004-2007 jako projekt badawczy nr 2 P06R 07327 
presented, whereas in the second part the effects of these media on the plant flowering and decorative value were evaluated.

\section{MATERIALS AND METHODS}

Seeds of parviflorous cultivar of garden pansy 'Butterfly Yellow with Blotch' were the study material. They were sown on 1 September 2005 into sphagnum peat of pH 6.2, supplemented with Osmocote Exact LoStart at the dose $2.5 \mathrm{~g} \times \mathrm{dm}^{-3}$.

The seedlings at the stage of 3-4 leaves were planted into 14 media including 12 compost media from 4 kinds of composts prepared in the autumn of 2004 whose composition adjusted to the dry weight basis, was as follows: compost I - municipal sewage sludge $70 \%$ and rye straw $30 \%$; compost II - municipal sewage sludge $70 \%$ and coniferous tree sawdust $30 \%$; compost III - municipal sewage sludge $35 \%$, potato pulp $35 \%$ and rye straw 30\%; compost IV - municipal sewage sludge $35 \%$, potato pulp $35 \%$ and coniferous tree sawdust $30 \%$. Composts were fermented for 7 months. The origin of compost components, their chemical composition, composting process and chemical characteristics of compost are presented in the work of $\mathrm{Krzyw}$ et al. (2007). The media components were described in Part I. Two variants of control media were applied: control I - peat neutralised with chalk and dolomite to $\mathrm{pH} 6.0$ + Osmocote Exact Lo-Start 5-6M $(15+8+10)$, at the dose $5 \mathrm{~g} \times \mathrm{dm}^{-3}$; control 2 - peat neutralised with chalk and dolomite to $\mathrm{pH} 6.0+$ Azofoska $(13.6+6.4+19.1)$, at the dose

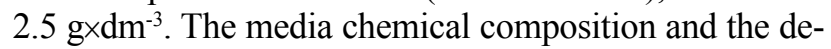
tailed course of experiments were given in Part I.

Morphological measurements were taken in the spring of 2006 at full blooming (12.04.2006). The length and width of the first flower and the length of its flower stalk were measured, the flowers were counted at 9 dates and removed each time after counting. Valuation scale 1-9 had been developed. It was assumed that 1 indicates very poor quality (plants without flowers, of irregular conformation, poorly leaved) and 9 - the best quality (plants with flower, of regular conformation and dark green leaves). The obtained results were verified by means of analysis of variance for one-factor experiments at $\alpha=0,05$.

\section{RESULTS}

It was found that the pansies cultivated in the medium containing $75 \%$ of compost IV produced the largest flowers of the greatest width, the longest with the longest flower stalk (Tab. 1). However, as the analysis of variance showed their traits did not significantly differ from the plants growing in the other media, except the medium with Azofoska which produced the smallest flowers.
There were differences in the dynamics of flowering depending on the medium (Fig. 1). In the control media, more even flowering was observed in the medium with Osmocote Exact than in that with Azofoska. Although the pansies cultivated in the medium containing a slow-release fertiliser formed the most flowers, statistical differences in the number of flowers were not confirmed. In the media containing compost I made from sewage sludge $(70 \%)$ and straw $(30 \%)$, at an initial stage the fastest and most abundant flowering was observed in the pansies from the cultivation with $25 \%$ of compost, but at the end of flowering the plants from the medium 4 with $50 \%$ of compost I had more flowers. As far as the abundance of flowering is concerned, these pansies did not differ from the control plants and among themselves. Among the pansies cultivated in the media with compost II ( $70 \%$ sewage sludge and $30 \%$ sawdust), those from the medium 6 were inferior to other plants in terms of flowering, especially at the end of the generative stage. Finally, in relation to the plants cultivated with Osmocote Exact and in the medium with $50 \%$ of compost II, they obtained statistically fewer flowers on the average by 38.4 and $33.9 \%$, respectively.

The comparison of pansy flowering from all the media proved that it was the poorest in medium 9, containing $25 \%$ of compost III (sewage sludge $35 \%$, potato pulp $35 \%$, straw $30 \%$ ). The pansies growing in this medium had fewer flowers in a whole season than those from the media with 50 and $75 \%$ of compost III, but there were no statistically significant differences in the number of flowers. In comparison with the control plants (medium 1 and 2), the pansies from medium 9 had by $43.5 \%$ and $33.9 \%$ fewer flowers on the average. The evaluation of flowering in the pansies from the media containing compost IV (sewage sludge $35 \%$, potato pulp 35\%, sawdust 30\%) revealed even, in a whole season, and abundant flowering in the pansies from $50 \%$ of compost IV but compared to control and other variants with compost IV, the differences in the number of flowers were statistically insignificant. In general, the most intensive flowering occurred after the application of compost with peat at the ratio $1: 1$.

From the beginning of cultivation to flowering, the best decorative value was observed in the pansies cultivated in peat with Osmocote Exact (Fig. 2). In compost media flowering varied, the most beautiful pansies were obtained from the media with $25 \%$ of compost I and $75 \%$ of compost II. The application of compost III and IV with peat at the ratio 1:1 was more justified and had a more favourable effect on the decorative value of pansies.

\section{DISCUSSION}

The studies conducted by Startek (2002) show that during intensive growth and flowering pansies 
Table 1

Effects of compost media on quality of garden pansy flowering.

\begin{tabular}{|c|c|c|c|}
\hline Medium & $\begin{array}{c}\text { Length } \\
\text { of flower } \\
{[\mathrm{cm}]}\end{array}$ & $\begin{array}{c}\text { Width } \\
\text { of flower } \\
{[\mathrm{cm}]}\end{array}$ & $\begin{array}{c}\text { Length } \\
\text { of flower stalk } \\
{[\mathrm{cm}]}\end{array}$ \\
\hline $1-$ Peat + Osmocote - control 1 & $2.42 \mathrm{ab}$ & $2.21 \mathrm{ab}$ & $3.92 \mathrm{ab}$ \\
\hline $2-$ Peat + Azofoska - control 2 & $2.16 \mathrm{~b}$ & $1.95 \mathrm{~b}$ & $3.56 \mathrm{ab}$ \\
\hline $3-25 \%$ compost I* + 75\% peat & $2.69 \mathrm{ab}$ & $2.39 \mathrm{ab}$ & $4.37 \mathrm{ab}$ \\
\hline $4-50 \%$ compost I $+50 \%$ peat & $2.44 \mathrm{ab}$ & $2.29 \mathrm{ab}$ & $3.40 \mathrm{~b}$ \\
\hline $5-75 \%$ compost I $+25 \%$ peat & $2.62 \mathrm{ab}$ & $2.36 \mathrm{ab}$ & $4.17 \mathrm{ab}$ \\
\hline $6-25 \%$ compost II $+75 \%$ peat & $2.43 \mathrm{ab}$ & $2.22 \mathrm{ab}$ & $3.68 \mathrm{ab}$ \\
\hline $7-50 \%$ compost II $+50 \%$ peat & $2.48 \mathrm{ab}$ & $2.27 \mathrm{ab}$ & $4.04 \mathrm{ab}$ \\
\hline $8-75 \%$ compost II $+25 \%$ peat & $2.77 \mathrm{ab}$ & $2.56 \mathrm{ab}$ & $4.37 \mathrm{ab}$ \\
\hline $9-25 \%$ compost III $+75 \%$ peat & $2.71 \mathrm{ab}$ & $2.53 \mathrm{ab}$ & $4.49 \mathrm{ab}$ \\
\hline $10-50 \%$ compost III $+50 \%$ peat & $2.83 \mathrm{ab}$ & $2.62 \mathrm{ab}$ & $4.58 \mathrm{ab}$ \\
\hline $11-75 \%$ compost III $+25 \%$ peat & $2.40 \mathrm{ab}$ & $2.20 \mathrm{ab}$ & $3.86 \mathrm{ab}$ \\
\hline $12-25 \%$ compost IV $+75 \%$ peat & $2.64 \mathrm{ab}$ & $2.49 \mathrm{ab}$ & $4.23 \mathrm{ab}$ \\
\hline $13-50 \%$ compost IV $+50 \%$ peat & $2.98 \mathrm{ab}$ & $2.65 \mathrm{ab}$ & $4.81 \mathrm{ab}$ \\
\hline $14-75 \%$ compost IV $+25 \%$ peat & $3.23 \mathrm{a}$ & $2.98 \mathrm{a}$ & $5.14 \mathrm{a}$ \\
\hline Mean & 2.63 & 2.41 & 4.187 \\
\hline LSD 0.05 & 0.847 & 0.779 & 1.581 \\
\hline
\end{tabular}

* Media components adjusted to dry matter:

Compost I - municipal sewage sludge $70 \%$, rye straw $30 \%$;

Compost II - municipal sewage sludge $70 \%$, saw dust from coniferous trees $30 \%$;

Compost III - municipal sewage sludge $35 \%$, potato pulp $35 \%$, rye straw $30 \%$;

Compost IV - municipal sewage sludge $35 \%$, potato pulp $35 \%$, saw dust from coniferous trees $30 \%$.

14.04. $\square 20.04 \quad \square 27.04 \quad \square 4.05 . \quad \square 11.05 . \quad \square 17.05 . \quad \square 25.07 \quad \square 1.06 . \quad \square 8.06$.

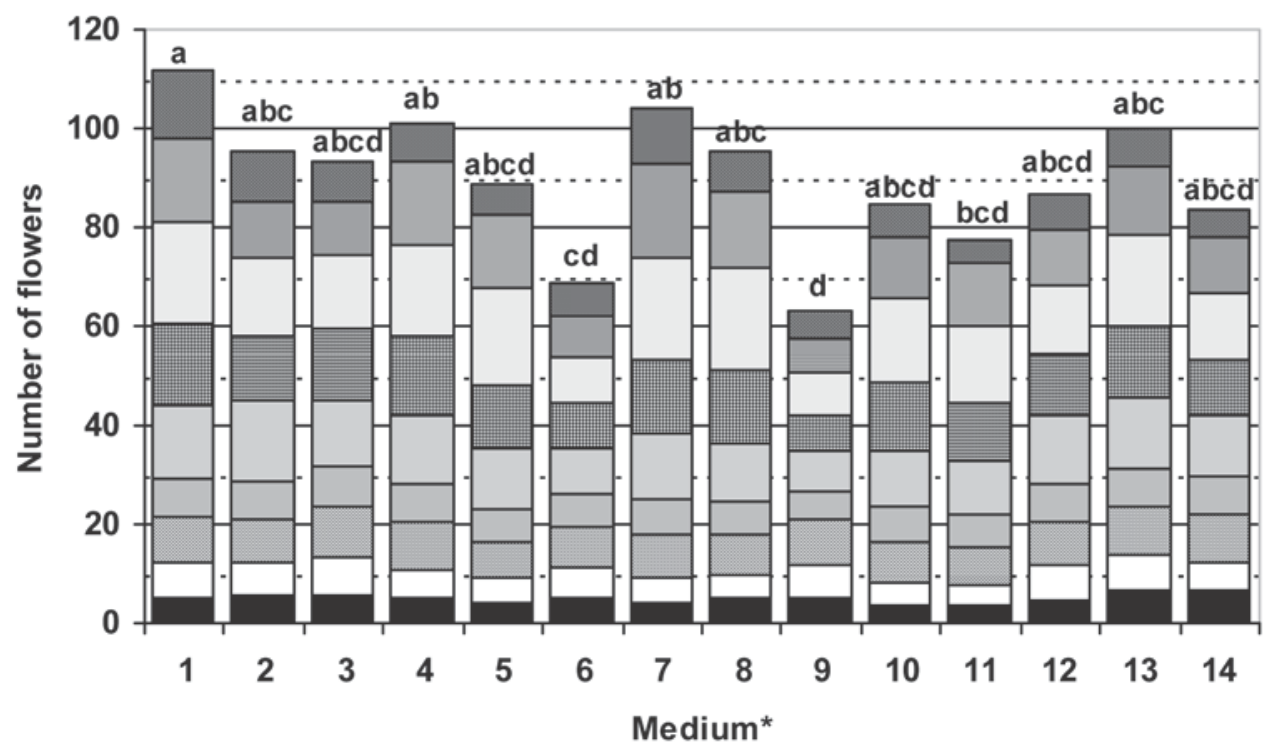

* Media marked as in Table 1

** a, b, c - means marked by the same letter do not differ significantly at $\alpha=0,05$

Fig. 1. Flowering dynamics of 'Butterfly Yellow with Blotch' (beginning of flowering - 1st decade of June) cultivated in compost media. 


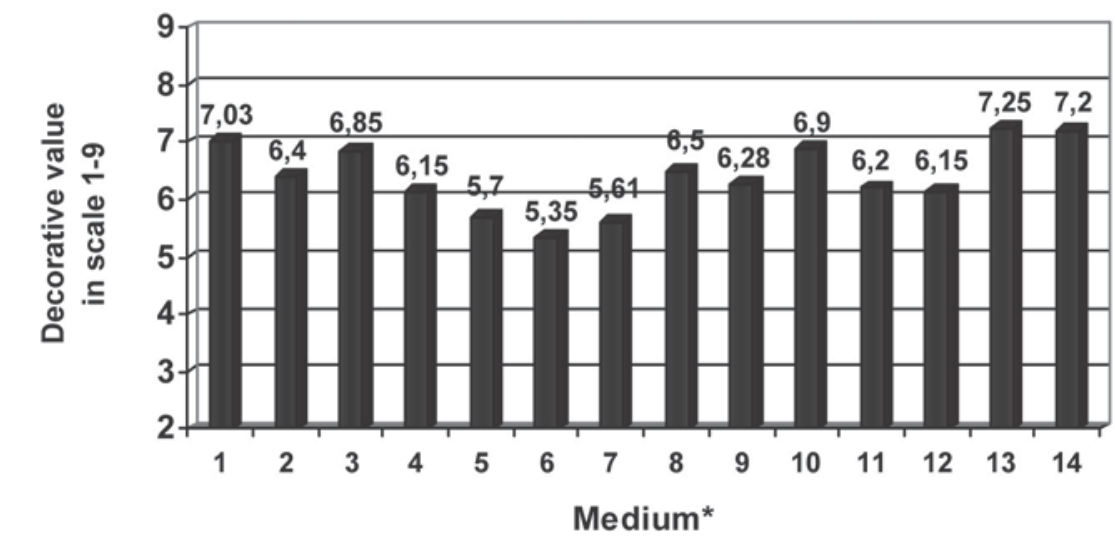

* Media marked as in Table 1

Fig. 2. Valuation scale of garden pansy at flowering stage.

have great nutrient requirements and are tolerant to a high nutrient content in the medium. Nutrient deficiency or their uneven supply lowers pansy decorative value by deteriorating plant conformation, reducing the number of flowers and shortening the flowering period. In our studies the media with composts based on municipal sewage sludge rich in nutrients, but containing also heavy metals (K r z y w y et al. 2007), had a considerable effect on the course, abundance of flowering and decorative value of the cultivar 'Butterfly Yellow with Blotch'.

According to literature, the media for bedded plants cultivation may be supplemented with $20-50 \%$ of municipal sewage sludge, mixed with peat, since it is not rich in nutrients and neutralises the unfavourable effect of salinised sewage sludge with heavy metals. The studies on pelargonium conducted by Andre et al. (2002) demonstrated that even $50-100 \%$ of sewage sludge in the medium had a favourable influence on the plant growth, flower number and diameter, but slightly delayed flowering.

In our studies, there were no significant disproportions in the size of flowers, except the medium with Azofoska where the flowers were smaller as a result of nutrient exhaustion. The pansies from the medium containing $75 \%$ of compost from sewage sludge, potato pulp and sawdust had the largest flowers on long flower stalks. The most abundant flowering was observed in the plants grown in peat with Osmocote Exact, but no significant differences in comparison with the plants from Azofoska and the majority of compost media were found. The poorest flowering was noted in the case of pansies cultivated with $25 \%$ of compost II and III (medium 6 and 9), probably due to the chemical composition of the media (Krzy w y et al. 2007), which in April and May - after 8 months of cultivation (autumn sowing) - contained an insufficient amount of nitrogen and po- tassium. The pansies cultivated in medium 6 turned out to be the worst according to valuation scale, whereas those from the media containing 50 and $75 \%$ of compost IV (sewage sludge, potato pulp and sawdust) were rated very high, higher than those grown with Osmocote Exact. They had shapely conformation due to wide leaf rosettes, a great number of intensively green leaves and large flowers.

In the study of $\mathrm{Z}$ aw a d z in s k a and $\mathrm{K}$ le s s a (2007) on pelargonium, 50\% compost supplement from sewage sludge, potato pulp and straw or sawdust did not affect the flower and inflorescence size, but weakened flowering without any effect on the plant decorative value throughout the experiment. Also, New Guinea Impatiens in the experiments conducted by $\mathrm{S}$ tartek et al. (2006b) proved to be decorative during the whole season, but its flowering was less abundant than in the medium containing a slow-release fertiliser.

Certain plant species may respond to the presence of sewage sludge in the media with poorer growth and flowering, e.g. Lysimachia congestiflora or Gloxinia sylvatica (Wils on et al. 2002). Plant response depends, first of all, on their tolerance to medium salinity and $\mathrm{pH}$, and the presence of heavy metals. The origin of municipal sewage sludge and the degree of maturity of applied composts is of great importance.

\section{CONCLUSIONS}

1. Pansy flowers cultivated in the compost media do not significantly differ in their size from those cultivated with the addition of Osmocote Exact, whereas those from peat with Azofoska are the smallest.

2. The most abundant flowering is obtained in the pansies for whose cultivation a slow-release fertiliser is applied, but the plants cultivated in the compost with peat at the ratio $1: 1$ produce equally abundant flowering. 
3. At the generative stage, the pansies from the control media and those with the supplement of $25 \%$ of compost I, $75 \%$ of compost II and $50 \%$ of compost III and IV are the most decorative.

4. On the basis of plant valuation scale, quality analysis and abundance of flowering, the media containing $50 \%$ compost supplement are found to be the best for pansy cultivation.

\section{REFERENCES}

Andre F., Guerrero C., Beltrao J., Brito J., 2002. Comparative study of Pelargonium sp. grown in sewage sludge and peat mixtures. Acta Hort. 573: 63-69.

Garcia-Gomez A., Bernal M. P., Roig A., 2002. Growth of ornamental plants in two composts prepared from agroindustrial wastes. Bioresource Technol. 83: 81-87.

Krause J., Lisiecka A., Szczepaniak S., 2006. Annual and biennial ornamental plants. Wyd. AR, Poznań, 175 ss.

Krzywy E., Zawadzińska A., Klessa M., 2007. Usefulness studies on media with additional sewage sludge composts for ornamental plants cultivation. Zesz. Prob. Post. Nauk Rol. 518: 101-110.

Startek L., 2002. Effects of the substrate and fertilization on growth dynamics, flowering and permanence of decorative value of garden pansies Viola $\times$ wittrockiana Gams. Zesz. Probl. Post. Nauk Rol. 484: 629-636.

Startek L. 2003. Cultivation facilities and decorative value of garden pansy. Rośliny Ozdobne, 2: 16-18.

Startek L., Janicka D., Dobrowolska A., Placek M., 2006a. The effects of medium on emergence dynamics and the length of vegetative stage of pansy belonging to Carrera and Butterfly groups. Zesz. Prob. Post. Nauk Rol. 510: 601-608.

Startek L., Placek M., Klessa M., 2006b. Effect of medium and fertilization on New Guinea Impatiens cultivars 'Sonic Amethyst' and Super Sonic Lilac'. Zesz. Prob. Post. Nauk Rol. 510: 609-617.

Wilson S. B., Stoffella P. J., Graetz D. A., 2002. Development of compost-based media for containerized perennials. Sci. Hortic. 93: 311-320.

Zawadzińska A., Klessa M., 2007. Effect of municipal sewage sludge and potato pulp composts on growth and flowring of Pelargoniom $\times$ hortorum (Bailey). Zesz. Probl. Post. Nauk Rol. (po recenzji).

\section{Wpływ podłoży kompostowych na wzrost i kwitnienie bratków ogrodowych z grupy drobnokwiatowych}

\section{Cz. 2. Kwitnienie i wartość dekoracyjna roślin}

\section{Streszczenie}

Celem badań było sprawdzenie wpływu podłoży zawierających komposty $\mathrm{z}$ osadów komunalnych i wycierki ziemniaczanej na kwitnienie i wartość dekoracyjną bratków odmiany 'Butterfly Yellow with Blotch' z grupy drobnokwiatowych. W doświadczeniu testowano 14 podłoży, w tym 12 podłoży kompostowych, skomponowanych z 4 kompostów, których udział w mieszance $z$ torfem wysokim wynosił 25,50 i $75 \%$. Skład rzeczowy kompostów był następujący: I - komunalny osad ściekowy $70 \%$ i słoma $30 \%$; II - komunalny osad ściekowy $70 \%$ i trociny $30 \%$; III - komunalny osad ściekowy $35 \%$, wycierka ziemniaczana $35 \%$ i słoma $30 \%$; IV - komunalny osad ściekowy $35 \%$, wycierka ziemniaczana $35 \%$ i trociny $30 \%$. Zastosowano 2 podłoża kontrolne na bazie torfu wysokiego: 1 - torf $\mathrm{z}$ nawo-



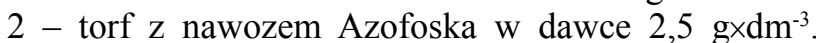
Nie stosowano nawożenia pogłównego w trakcie uprawy.

Stwierdzono, że najwięcej kwiatów miały bratki, do uprawy których zastosowano nawóz o spowolnionym działaniu, ale równie obficie kwitty rośliny uprawiane $\mathrm{w}$ kompostach $\mathrm{z}$ torfem, w proporcji 1:1. W stadium generatywnym najbardziej dekoracyjne były bratki w podłożach kontrolnych oraz bratki, do uprawy których zastosowano 25\% kompostu I, 75\% kompostu II i 50\% kompostu III i IV. Na podstawie oceny bonitacyjnej roślin, analizie jakości i obfitości kwitnienia stwierdzono, że optymalne do uprawy bratka były podłoża zawierające $50 \%$ kompostów. 


\title{
ACTA AGROBOTANICA \\ Vol. 60 (2) 2007
}

\author{
AUTHOR INDEX
}

Irena Giełwanowska, Anna Bochenek, Ewa Szczu$\mathrm{ka}$ : Development of the pollen in the Antarctic flowering plant Colobanthus quitensis (Kunth) Bartl.

Agata Pacek, Małgorzata Stpiczyńska: The structure of elaiophores in Oncidium cheirophorum Rchb f. and Ornithocephalus kruegeri Rchb.f. (Orchidaceae)

Elżbieta Weryszko-Chmielewska, Mirosława Chwil, Magdalena Michońska: Micromorphology of nectaries of Rhododendron catawbiense Michx. at different flower development stages

Agata Konarska: Characteristics of the surface of the epidermis in floral nectaries and the receptacle of mountain ash (Sorbus aucuparia L.)

Bartosz Jan Płachno: "Sweet but dangerous": nectaries in carnivorous plants

Alina Trejgell, Andrzej Tretyn: Analysis of flowering ability of regenerated Carlina acaulis subsp. simplex plants.

Marcin Zych, Paweł Niemczyk, Radosław Niemirski: Umbellifers as potential keystone species in restoration project

Idalia Kasprzyk, Adam Walanus:Flowering and airborne pollen - a novel statistical approach

Irena Agnieszka Pidek: Nine-year record of Alnus pollen deposition in the Roztocze region (SE Poland) with relation to vegetation data

Małgorzata Puc: The effect of meteorological conditions on hazel (Corylus spp.) and alder (Alnus spp.) pollen concentration in the air of Szczecin

Dorota Myszkowska, Bartosz Jenner, Katarzyna Cywa, Monika Kuropatwa, Danuta Stępalska, Katarzyna Piotrowicz: Pollen seasons of selected tree and shrub taxa in Kraków and its neighbourhood $\quad 71$

Kazimiera Chłopek: Grass pollen (Poaceae) in the air of Sosnowiec (Poland), $1997-2006$
Elżbieta Weryszko-Chmielewska, Piotr Rapiejko: Analysis of Alnus spp. pollen seasons in Lublin and Warszawa (Poland), 2001-2007

Agnieszka Grinn-Gofroń: Cladosporium spores in the air of Szczecin

Bożenna Czarnecka, Magdalena Franczak, Katarzyna Now ak: Reproductive effort as an element of life strategy of Lythrum salicaria L. populations

105

Anna Katarzyna Sawilska: The influence of origin of $\mathrm{He}$ lichrysum arenarium (L.) Moench individuals on their inflorescence yield and germination ability

Małgorzata Wrzesień, Bożena Denisow: The phytocoenoses of anthropogenically transformed areas with a great importance for Apoidea

117

Renata Nurzyńska-Wierdak: Comparing the growth and flowering of selected basil (Ocimum basilicum L.) varieties

Danuta Sugier: The flowering pattern of Arnica montana L. and $A$. chamissonis Less. under field cultivation conditions with successive flower head collection

Grażyna Zawiślak: Growth and flowering of two Leuzea species

Krzyszt of Gęsiński: Effect of the kind of habitat on flowering of Hierochloë repens (Host) Simonkai

Helena Łabuda, Anna Brodaczewska: The influence of environmental factors on flowering of french bean (Phaseolus vulgaris $\mathrm{L}$.)

153

Agnieszka Zawadzińska, Dorota Janicka: Effects of compost media on growth and flowering of parviflorous garden pansy (Viola $\times$ wittrockiana Gams.) ${ }^{*}$. Part I. Plant growth and conformation

161

Agnieszka Zawadzińska, Dorota Janicka: Effects of compost media on growth and flowering of parviflorous garden pansy (Viola $\times$ wittrockiana Gams.). Part II. Plant flowering and decorative value

167 
